\title{
REVIEWS
}

\section{Microbial life under extreme energy limitation}

\section{Tori M. Hoehler ${ }^{*}$ and Bo Barker Jørgensen ${ }^{2 *}$}

Abstract |A great number of the bacteria and archaea on Earth are found in subsurface environments in a physiological state that is poorly represented or explained by laboratory cultures. Microbial cells in these very stable and oligotrophic settings catabolize $10^{4}$ - to $10^{6}$-fold more slowly than model organisms in nutrient-rich cultures, turn over biomass on timescales of centuries to millennia rather than hours to days, and subsist with energy fluxes that are 1,000-fold lower than the typical culture-based estimates of maintenance requirements. To reconcile this disparate state of being with our knowledge of microbial physiology will require a revised understanding of microbial energy requirements, including identifying the factors that comprise true basal maintenance and the adaptations that might serve to minimize these factors.

Deep biosphere

The set of ecosystems and their organisms living beneath the upper few metres of the solid earth surface.

Extended stationary phase A phase of the batch culture life cycle characterized by the persistence of a small fraction of cells for months to years beyond the death of the majority of the culture, without new addition of substrate.
'NASA Ames Research Center, Mail Stop 239-4, Moffett Field, California 94035-1000, USA. ${ }^{2}$ Center for Geomicrobiology, Institute of Bioscience, Aarhus University, Ny Munkegade 114, 8000 Aarhus C, Denmark. *The authors contributed equally to this work. Correspondence to T.M.H. e-mail: doi:10.1038/nrmicro2939
The discovery of microbial life beneath the surface of the continents and the seabed has shown that a large proportion of all the bacteria and archaea on Earth live in the deep biosphere ${ }^{1}$ and that the energy supply for microbial life that is present in this environment spans many orders of magnitude. Even though so many microorganisms reside in the deep biosphere - about $3 \times 10^{29}$ cells according to the most recent census ${ }^{2}-$ the energy flux available from buried organic carbon is less than $1 \%$ of the photosynthetically fixed carbon on the surface of our planet ${ }^{1}$. These microorganisms generally have no cultivated relatives, and their biochemistry and physiology are largely unknown. One of the greatest enigmas, however, is how these vast communities can subsist in conditions that provide only marginal energy for cell growth and division and seem to barely support the maintenance of basic cellular functions.

This Review explores the range of metabolic states in cultivated cell populations under feast and famine conditions and compares the lessons learned from laboratory cultures with our knowledge of energy-depleted environmental conditions. We present current estimates of mean metabolic rates in natural communities and discuss whether highly energy-starved microorganisms have previously unexplored physiological mechanisms to cope with low energy flux.

\section{Energy metabolism in culture}

Most of our knowledge about microbial physiology and metabolism is derived from the study of organisms in batch culture, but the pace of life, the physiological states and the prominent organisms differ widely from the Petri dish to the environment. Particularly when considering oligotrophic natural systems such as the deep biosphere, it is important to bear in mind that our understanding of microbial energy metabolism stems primarily from studying populations that are characterized by rapid growth, high metabolic rates and high cell densities - characteristics that do not apply to most microorganisms in nature.

The phases of life in batch culture. Populations in batch culture transition through lag phase, exponential phase, stationary phase, death phase and extended stationary phase (FIG. 1). The most heavily studied aspects of the microbial life cycle are the growth (exponential) and stationary phases. Growth phase is characterized by cells operating at rates near the maximum allowed by their enzyme kinetics (growing in exponential fashion) and dividing with a time constant that is determined by the physiology of the organisms concerned and the growth conditions. Compilations across a broad range of cultured $\operatorname{taxa}^{3-7}$ show maximum growth rates that generally cluster within a two orders of magnitude range, from less than $1 \mathrm{~d}^{-1}$ to more than $30 \mathrm{~d}^{-1}$. At the high end of this range, populations double in less than 30 minutes, and for the discussion that follows it is useful to recall that a typical culture of Escherichia coli has a doubling time of about 20 minutes and transitions through the lag-to-death batch culture life cycle within about 3 days ${ }^{8}$.

Following stationary phase, most of the population - typically $99 \%$ or more in batch cultures of $E$. coli 


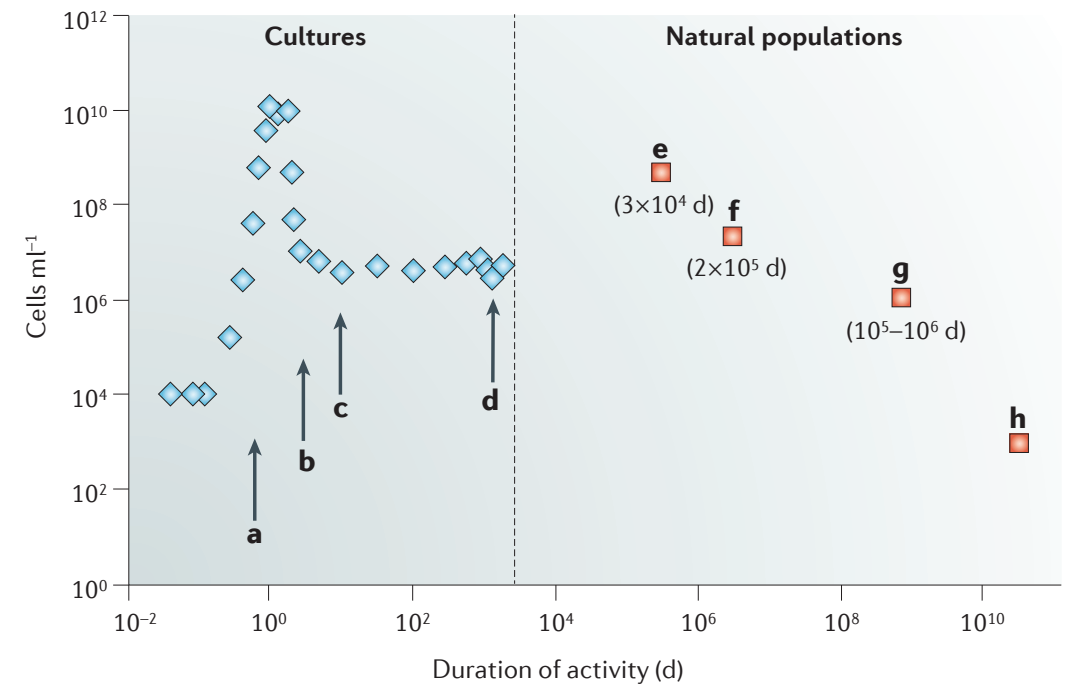

Figure 1 | Timescales, population sizes and biomass turnover times associated with culture-based and natural environment studies. Blue points represent a hypothetical batch culture experiment for an organism with a $1 \mathrm{~h}$ doubling time (after Finkel ${ }^{8}$ ). Red points reflect measurements in natural systems. Values in parentheses represent estimates of carbon turnover in terms comparable to doubling time. Time points of note are (a) 1 day: end of exponential growth; (b) 3 days: end of classical batch culture life cycle; (c) 10 days: emergence of GASP mutants; (d) 5 years: approximate duration over which 'extended stationary phase' has been studied; (e) 500 years: Aarhus Bay sediments at 20 cmbsf (centimetres below sea floor) ${ }^{70,71}$; (f) 5,000 years: Aarhus Bay sediments at 3 mbsf (metres below sea floor) ${ }^{70,71} ;$ (g) 2 million years: Peru margin sediments at 100 mbsf $^{65}$; (h) 86 million years: North Pacific Gyre sediments at $30 \mathrm{mbsf}^{16}$. The majority of our knowledge about microbial physiology derives from the region approximated by $\mathbf{a}$, whereas a large proportion of bacteria and archaea on Earth live in circumstances approximated by $\mathbf{e}-\mathbf{h}$.

\section{$Y_{\text {ATP }}$}

Cellular growth yield normalized to ATP consumption.
- becomes non-viable ${ }^{8}$. The onset and extent of cell death within a given species is reproducible ${ }^{9,10}$, but the mechanisms responsible are not well understood. Finkel ${ }^{8}$ suggests two possibilities. Cell death might simply result from exhaustion of resources and consequent inability to support a high-density population, or by accumulation of inhibitory substances; the energy and nutrients provided by the death and lysis of a fraction of the cells can then support the remaining viable fraction. Alternatively, cell death could be a programmed response that is induced by the sensing of high cell density and resource limitation, with subsequent sensing of newly sustainable conditions following the death of most of the population inducing the survivors to exit the programmed death pathway. The cause and rate of cell death are crucially important in the context of low-energy environments because the energy required to support a steady-state population varies dramatically depending on the level of cell turnover within that population. Biosynthesis is energetically costly. The need to constantly resynthesize whole cells (as opposed to coping with molecular attrition within a cell) would greatly increase the effective per-cell energy needed to support a steady-state population and might exclude many low-energy environments from habitation. Importantly, from this perspective, both of the mechanisms envisioned to initiate cell death relate to high population densities and resources that can be rapidly depleted $^{8}$. In both mechanisms, but particularly the second, batch culture conditions are not representative of the conditions found in low-energy environments. Thus it is not clear whether, or to what extent, the death that occurs in batch cultures is part of microbial life under low energy flux.

The small fraction of cells that survive through the death phase (which, even at a 99\% attrition rate, can still comprise cell densities of $10^{6}-10^{7} \mathrm{ml}^{-1}$ ) has been shown to persist for months or years without further addition of substrate, forming what has been referred to as an extended stationary phase $e^{8,10,11}$. Among the states represented in batch culture, extended stationary phase would seem the most relevant for understanding life in lowenergy environments, but it must be borne in mind that there are key differences in the nature of energy provision and the relevant timescales and thus, potentially, also in the prevailing physiological states. Extended stationary phase in E. coli is characterized by the rapid emergence of at least four distinct mutations that enhance the ability to catabolize amino acids ${ }^{12-14}$ - that is, to subsist on the remains of dead predecessors - and thereby confer a growth advantage relative to wild-type cells or even earlier generations of survivors ${ }^{9,10}$. The emergence and succession of these growth advantage in stationary phase (GASP) mutants drives population turnover that occurs on monthly or shorter timescales and that can persist for more than a year ${ }^{10,15}$. Such dynamic overturn in the population (with relatively high rates of growth replacing cell attrition) reflects an energy-intensive state that is driven by the initial availability of 100-1,000 dead cells' worth of energy for each survivor of death phase. Because it seems unlikely that such dynamism could be supported over the much longer timescales that are characteristic of sustained microbial activity in natural settings ${ }^{16}$, caution is warranted in considering even the extended stationary phase as a model for life in low-energy settings.

Energy partitioning: $Y_{\text {ATP }}$ growth and maintenance. The energy yield of substrate catabolism is partitioned among various cellular functions, including both those that are related to and those that are not related to growth ${ }^{17-19}$. The demonstration that energy is diverted to processes other than growth is well illustrated by the growth yield parameter $Y_{\text {ATP }}{ }^{20}$. Equating growth to the catabolic yield of ATP, rather than to substrate consumption, facilitates direct comparison of growth yield across different taxa and substrate ${ }^{18,20}$, and permits theoretical estimates of the biomass yield if ATP were used exclusively for growth ${ }^{21}$. The many determinations of $Y_{\text {ATP }}$ in cultures have demonstrated that the true yield almost always falls significantly short of the theoretical maximum (in E. coli, $Y_{\text {ATP }}$ is about one-third of theoretical maximum ${ }^{21}$ ), meaning that a substantive fraction of energy is diverted to functions other than growth ${ }^{22}$. Reported values for $Y_{\text {ATP }}$ vary by fivefold across different organisms and growth conditions ${ }^{21,23}$, indicating that the amount of energy diverted to non-growth functions is highly variable. Some of the energy diverted away from growth can be understood as 'maintenance energy' - the flux of energy needed to sustain a steady-state population of cells without net growth ${ }^{24,25}$ (BOX 1). 


\section{Box 1 | Maintenance energy}

"How would we express in terms of statistical theory that marvellous faculty of a living organism, by which it delays the decay into thermodynamic equilibrium (death)? ... 'It feeds upon negative entropy'." - Erwin Schrödinger ${ }^{121}$

It has been understood for more than a century that life must require a minimal flux of energy to support standing biomass without net growth ${ }^{122}$, but the contributors to 'maintenance energy' are not well characterized or quantified, and laboratory estimates exceed by many orders of magnitude the energy fluxes that appear to support life under conditions of low energy flux. The challenge is summarized by van Bodegom ${ }^{19}$ : "Many microbial ecologists have a clear concept on the processes entangled in physiological maintenance or endogenous metabolism, but this is not what is measured empirically." Pirt ${ }^{24}$ described maintenance as "energy consumed for functions other than production of new cell material", providing an operational definition upon which to base observations (see below). But this is more a description of what maintenance is not than of what it is, and contributions to this pool can vary widely depending on the physiological state of the population. Van Bodegom defines eight distinct categories of non-growth functions to which energy can be diverted, and which are included in empirical determinations of maintenance energy ${ }^{19}$ : shifts in metabolic pathways, energy spilling reactions, cell motility, changes in stored polymeric carbon, osmoregulation, extracellular losses of compounds not involved in osmoregulation, proofreading, synthesis and turnover of macromolecular compounds such as enzymes and RNA, and defence against $\mathrm{O}_{2}$ stress. It is clear that these vary in relative importance depending on the organism in question, its environment and its metabolic rate, and that several factors that are large contributors at high metabolic rate are not requirements for minimal maintenance.

Most empirical determinations of maintenance energy have been made in chemostats, in which continuous flow of medium supplies substrate at a constant rate and likewise dilutes the microbial population at a constant rate ${ }^{24-26,123}$. Part a of the figure shows a simplified schematic of a chemostat. The experimenter varies the dilution rate (medium inflow rate divided by total volume of medium), which at steady state equals the growth rate, $\mu$, and observes the concentration of substrate in the effluent (to determine substrate consumption rate) and the standing biomass within the culture at steady state.

New cell growth balances cell removal, with a resulting steady-state population size that is dependent on energy flux. Operationally, population sizes are measured across a range of dilution rates, and maintenance energies are determined by extrapolating the results to a hypothetical zero-dilution (zero growth) condition ${ }^{18,124}$. Part $\mathbf{b}$ of the a

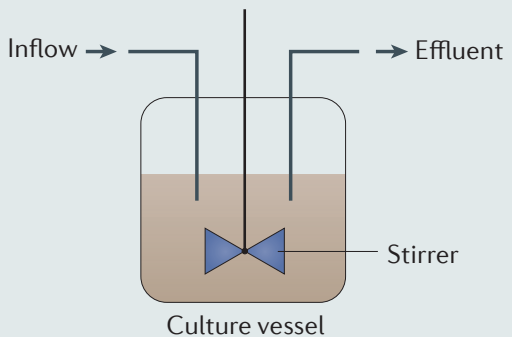

b

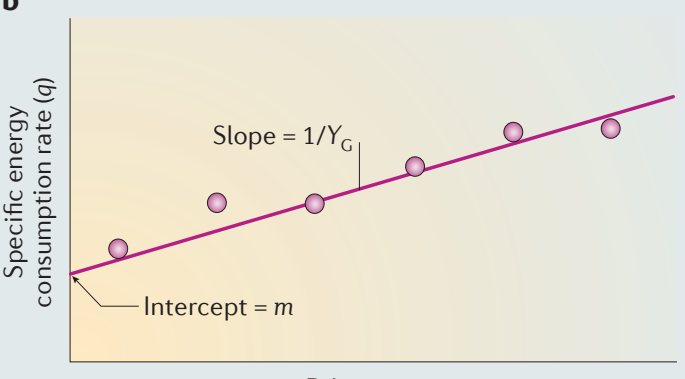

Dilution rate

figure shows a Tempest-type plot for estimating the maintenance coefficient, $m$, based on the relationship $q=\mu / Y_{\mathrm{C}}+m$. Here, $\mu$, the growth rate (in units of inverse time), is equal to the experimentally varied dilution rate; and $q$, the specific energy consumption rate (in units of, for example, mol substrate $\mathrm{g}$ biomass ${ }^{-1} \mathrm{~h}^{-1}$ ), is calculated from the observed rate of substrate depletion and the steady state biomass or population size. The slope of the plot gives the inverse of the growth yield, $Y_{G}$, and the intercept (extrapolation to a hypothetical zero growth condition), gives the maintenance coefficient, $m$.

The ability to achieve very low growth rates is limited in practice, because dilution rates $<0.05 \mathrm{~h}^{-1}$ (corresponding to a population doubling time of approximately 14 hours) can result in heterogeneity of the population and/or the conditions within the chemostat ${ }^{125}$. Thus, it should be borne in mind that chemostat-based observations always reflect a physiological state of active growth at metabolic rates that are much higher than those in energy-starved natural populations. Continued development of culture methodology might help to address these limitations. 'Retentostats' seek to maintain a true zero-growth condition by retaining biomass using filter elements ${ }^{32,38,39}$, and microfluidic chemostats $\mathrm{s}^{36,37}$ do the same by supplying substrates via diffusion through chamber walls that are impassable to cells - promising steps towards accessing the physiological states that are relevant for understanding life in energy-starved environments.
The advent of continuous culture (chemostat) techniques provided a standard methodology for determining maintenance energy ${ }^{26,27}$. Tijhuis and colleagues compiled more than 80 chemostat-based determinations of maintenance energy to develop a biomass-specific Gibbs energy consumption term ${ }^{28}$. The compiled values ranged from 2.2 to $365 \mathrm{~kJ} \mathrm{C} \mathrm{mol} \mathrm{biomass}{ }^{-1} \mathrm{~h}^{-1}$ with a suggested exponential (Arrhenius-like) dependence on temperature. In the cell-specific units utilized below (and assuming $1 \mathrm{C}$ mol biomass $=24.6 \mathrm{~g}$ dry biomass and an average dry cell mass of $10^{-13} \mathrm{~g}$ ), the derived correlation predicts a maintenance energy for anaerobes at $25^{\circ} \mathrm{C}$ of $3.3 \times 10^{-13} \mathrm{~kJ} \mathrm{cell}^{-1} \mathrm{~d}^{-1}$. For perspective, the predicted maintenance energy for anaerobes at human body temperature of $37^{\circ} \mathrm{C}, 9.7 \mathrm{~kJ} \mathrm{C} \mathrm{mol} \mathrm{biomass}{ }^{-1} \mathrm{~h}^{-1}$, can be compared with an approximate human dietary intake of about $0.37 \mathrm{~kJ} \mathrm{C} \mathrm{mol} \mathrm{biomass}{ }^{-1} \mathrm{~h}^{-1}$ (for an example case with $10,000 \mathrm{~kJ} \mathrm{~d}^{-1}$ and $70 \mathrm{~kg}$ biomass consisting of $60 \%$ 
Basal power requirement Energy turnover rate per cell or per unit biomass associated with the minimal complement of functions required to sustain a metabolically active state of the cell.

Mean cell-specific metabolic rates

Estimate of average cellular metabolic rate among a whole community of cells obtained by measurement of bulk metabolic process rates and cell numbers.

Primary productivity The formation of living organic biomass from carbon dioxide through the process of photosynthesis or chemosynthesis.

\section{Reaction-transport}

modelling

Calculation of metabolic process rates based on steady-state concentrationdepth profiles and calculated metabolite fluxes.

Power law

A mathematical relationship between two quantities describing how one quantity,

$c$, varies as a power of another quantity, $z$ : for example,

$c=A \times Z^{-b}$, in which $c$ could be cell density, $z$ sediment depth

( $z>>0)$, and $A$ and $b$ constants. water weight). The fact that the chemostat-based maintenance value is 26 -fold higher than that for humans - who could hardly be envisioned as functioning near the minimal limits of required energy intake - emphasizes the need for caution in applying such values too literally to the question of life in low-energy environments. Indeed, Morita ${ }^{29,30}$ has suggested that maintenance energy requirements in natural settings can be 3-6 orders of magnitude lower, and a few chemostat and 'retentostat' studies ${ }^{31,32}$ have yielded values that are 2-3 orders of magnitude lower than those seen in the Tijhuis compilation.

In considering chemostat-based estimates of maintenance energy, it should be borne in mind that 'maintenance' is operationally defined as any energy not devoted to growth ${ }^{19,24,25}$, but this can comprise energy 'wasted' in spilling reactions ${ }^{33-35}$ and energy spent in 'useful' functions (for example, motility) that might become superfluous in highly energy-limited conditions ${ }^{19}$. To distinguish from this operational definition and the added energy costs it may comprise, we suggest the term basal power requirement to describe the energy flux associated with the minimal complement of functions required to sustain a metabolically active state. One challenge facing researchers in this area is the development of culturebased approaches in which basal power requirements can be quantified; efforts to modify continuous culture methodology for this specific purpose $\mathrm{e}^{32,36-39}$ and to bring microorganisms from low-energy natural settings into continuous culture $\mathrm{e}^{40,41}$ both hold promise in this regard. Importantly, however, although the state of basal maintenance might be elusive in culture, in nature it is probably expressed as the norm in low-energy communities. Here, the challenge is to accurately characterize the physiological states and identity of cells, along with the often extremely low process rates and cell numbers that are key to quantifying basal power requirements in the environment.

\section{Energy metabolism in the environment}

Measuring mean cell-specific metabolic rates. What are the maintenance states in energy-limited environments? The published data on the mean cell-specific metabolic rates of natural microbial communities, particularly the extremely low rates calculated for deep subsurface environments, are variable and often highly uncertain. One of the early problems in accurately characterizing deep communities - the retrieval of undisturbed and uncontaminated samples - can now be solved to a large extent by modern drilling and coring techniques (BOX 2). However, many additional challenges remain. The determination of mean cell-specific rates requires that bulk volumetric process rates and cell numbers be quantified in parallel, a criterion that has not often been met. Where it has been met, it is important to critically evaluate these results in light of the capabilities and limitations of the methods used to measure these parameters.

Whitman et al. ${ }^{1}$, who made the first bold extrapolation of bacterial and archaeal cell numbers to global biomass estimates, also estimated the average turnover time of bacterial and archaeal biomass. They assumed that about $1 \%$ of total net primary productivity reaches the subsurface and that the efficiency of cellular carbon assimilation is 0.2 . This implies that the mean turnover time of bacterial and archaeal biomass, and thus the mean generation time of bacterial and archaeal cells, is 1,000 years. From this surprisingly long generation time the authors concluded that most cells were probably inactive or even non-viable.

Parkes et al. ${ }^{42}$ used incubation experiments with ${ }^{35} \mathrm{~S}$-labelled sulphate to measure the rate of respiratory sulphate reduction in an ODP core from the continental shelf off Peru. They found peak rates of $0.46 \mathrm{nmol}$ $\mathrm{SO}_{4}{ }^{2-} \mathrm{cm}^{-3} \mathrm{~d}^{-1}$ at $1.5 \mathrm{~m}$ sediment depth with direct epifluorescence cell counts showing $1.3 \times 10^{9}$ cells $\mathrm{cm}^{-3}$. If it is assumed that one-tenth of the cells were sulphate reducers with a carbon assimilation efficiency of $2 \mathrm{~g}$ cell $\mathrm{C} \mathrm{mol}^{-1}$ substrate, then the mean rate of cell-specific carbon metabolism (calculated by dividing the rate of sulphate reduction per $\mathrm{cm}^{3}$ by the number of sulphate reducers per $\mathrm{cm}^{3}$ ) was $4 \times 10^{-4} \mathrm{fmol} \mathrm{SO}_{4}{ }^{2-}$ cell $^{-1} \mathrm{~d}^{-1}$ and the mean cell turnover was 30 years. Compared to more recent studies of sulphate reduction rates at similar sediment depth this rate is very high and might reflect the fact that experimental measurements of the sulphate reduction rate in deeper sediments tend to overestimate the in situ rate.

Rates of metabolism in natural systems can be quantified by directly measuring chemical transformation or by reaction-transport modelling. Incubations that track the turnover of radio-labelled substrates can be used to determine the rates of various processes ${ }^{43,44}$, but practical detection limits restrict their use in systems with very low metabolic rates ${ }^{45}$. Reaction-transport modelling of metabolic substrates or products can extend detectability to extremely low rates ${ }^{46-48}$. In systems with slow water flow - for example, terrestrial subsurface aquifers or mid-oceanic ridges - rates of metabolism can be estimated from the change in water chemistry in downstream boreholes divided by the flow velocity between the holes ${ }^{49-51}$. However, uncertainties in flow direction and velocity limit the accuracy of such estimates. Below, we focus on sedimentary environments where the restriction of mass transport predominantly to molecular diffusion allows for accurate modelling of substrate and product turnover.

The quantification of total microbial cell numbers in subsurface sediments is generally done by direct microscopy after fluorescent DNA staining ${ }^{52,53}$. At very low numbers, $<10^{5}$ cells cm$~^{-3}$, cells must first be extracted from the sediment before microscopic counting ${ }^{54}$. Cell numbers generally drop according to a power law from around $10^{9}$ cells $\mathrm{cm}^{-3}$ near the sediment surface to $10^{6}$ cells $\mathrm{cm}^{-3}$ hundreds of metres below ${ }^{1,55}$. Subsurface chemical interfaces, such as the zone where energy-rich methane from below diffuses up and meets sulphate-containing sediment, can have cell numbers $10^{2}-10^{3}$-fold above the mean ${ }^{45}$. Sediment environments with extremely low organic influx have cell numbers that can fall $10^{2}-10^{3}$ fold below the mean ${ }^{56,57}$. The practical detection limit set by counting statistics is currently around $10^{3}$ cells $\mathrm{cm}^{-3}$ (REF. 54). 


\section{Box 2 | Deep biosphere sampling}

The retrieval of uncontaminated sample material is a great challenge for research on the energy-deprived subsurface biosphere. Samples from deep sub-seafloor sediments are obtained during expeditions with one of the scientific drill-ships JOIDES Resolution or Chikyu, which are organized in international cooperation through the Integrated Ocean Drilling Program (IODP; or its earlier phase, the ODP). The consistent recovery and enumeration of cells in such carefully cored sediments is now accompanied by rigorous contamination controls ${ }^{55,126,127}$ : a dissolved perfluorocarbon tracer is introduced into the seawater that is pumped down into the drill hole to flush out suspended sediment and/or bacterial-size fluorescent beads are smeared around the cored sediment to check for possible penetration of micro-particles into the microbiology samples. Only non-contaminated sediment is used for microbiology research.

Scientific drilling is not exactly a sterile operation. However, sediment cores with an uncontaminated interior can now be brought rapidly on deck in transparent plastic liners and sectioned by scientists for microbiological and biogeochemical research (see the figure, parts $\mathbf{a}$ and $\mathbf{b}$, which show the drilling and preparation of a $9.5 \mathrm{~m}$-long sediment core in a plastic liner in the eastern tropical Pacific Ocean during ODP Expedition 201 on the JOIDES Resolution). Microorganisms can also be retrieved from the more shallow subsurface by gravity coring down to many metres or even tens of metres (see the figure, part c, which shows gravity coring in the Baltic Sea during the ABC-2010 Expedition by the Center for Geomicrobiology, Aarhus University). Microbiological subsampling from such cores can be done at high-depth resolution by techniques that avoid penetration of microorganisms into the inner part of the core (see the figure, part $\mathbf{d}$, also from the ABC-2010 Expedition).

Drilling of deep ocean crust along the mid-oceanic ridges or of subsurface sediment in tectonically active regions with flow of pore fluid poses very different demands on sampling techniques. This is also the case for most land-based drilling ${ }^{128,129}$. It is difficult to determine the in situ cell-specific metabolic rates in such systems, which have therefore not been included in this Review.

Photos in parts $\mathbf{C}$ and $\mathbf{d}$ courtesy of N. Risgaard-Petersen, Aarhus University, Denmark.
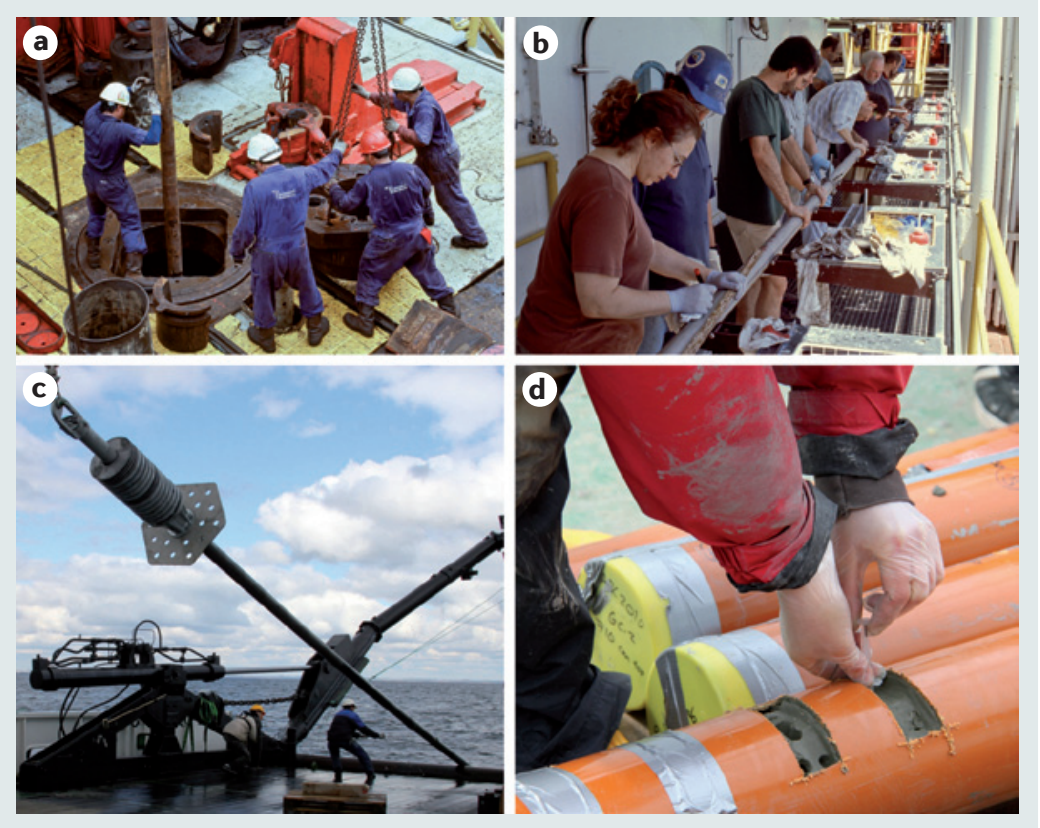

Quantification of phylogenetically or physiologically defined groups of microorganisms is done by fluorescence in situ hybridization (FISH) or catalysed reporter deposition FISH (CARD-FISH) targeting ribosomal RNA, or by quantitative PCR (qPCR) targeting the $16 \mathrm{~S}$ ribosomal RNA gene or genes that are diagnostic of distinct types of energy metabolism ${ }^{58}$ (such as the $d s r A$ gene, which encodes dissimilatory sulphite reductase, a metabolic enzyme found in sulphatereducing bacteria $\left.{ }^{59}\right)$. Such methods require previous knowledge of the sequence diversity in the targeted microorganisms and can be limited by insufficient specificity or coverage of the hybridization probes or primers used ${ }^{60}$. Sediment communities of bacteria and archaea can also be quantified from their intact polar membrane lipids ${ }^{61}$, assuming that these lipids originate from viable cells. However, archaeal lipids in particular can persist in the sediment after the death of the organisms, so a proportion of the extracted intact polar lipids can be of fossil nature ${ }^{62,63}$.

D'Hondt et al. ${ }^{64}$ calculated the total rate of sulphate reduction under $1 \mathrm{~m}^{2}$ of the sea floor from the gradient in pore water sulphate and the resulting molecular diffusion flux. For the open Pacific the sulphate flux downwards into the seabed past $1.5 \mathrm{~m}$ depth was then divided by the total cell number per $\mathrm{m}^{2}$ down through the sulphate zone. If it is assumed that one-tenth of the cells are sulphate reducers, the mean cell-specific rate in this deep and many million-years-old sediment would be $4 \times 10^{-6} \mathrm{fmol} \mathrm{SO}_{4}{ }^{2-}$ cell $^{-1} \mathrm{~d}^{-1}$, and the estimated mean cell turnover would be 3,000 years. It should be noted that this approach combines depth intervals of very different metabolic rates and very different cell numbers into one mean value, which will therefore be skewed relative to the cell-specific activity at any specific depth.

Lomstein et al. ${ }^{65}$ used a very different approach to calculate microbial turnover. Their approach is based on the built-in molecular clock in organic material in the form of amino acids that very slowly undergo spontaneous racemization to the alternative stereo-isomeric form: that is, $\mathrm{L}$-amino acids to the $\mathrm{D}$ form and vice versa ${ }^{66}$. By analysing the ratio between the $\mathrm{L}$ and $\mathrm{D}$ forms of aspartate in the pool of total hydrolysable amino acids, the authors could show that the bulk of subsurface amino acids in $>10^{6}$-year-old sediment were produced in situ by now-dead bacteria (necromass). A simple steady-state model (FIG. 2) was developed to calculate the turnover time of this bacterial necromass and thus the $\sim 100$-fold faster turnover of the $\sim 100$-fold smaller amino acid pool in living bacteria. The estimated turnover time of the total microbial biomass in deep subsurface sediment was 200-2,000 years, similar to the results obtained by Biddle et al. ${ }^{67}$ at the same site.

Cell-specific metabolic rates. Relatively few studies have simultaneously quantified both respiration rates and cell numbers in deep marine sediments. Here, we examine two such studies that reflect very different environments, processes, timescales and methods for quantifying metabolic rates. Despite these differences, the cell-specific metabolic rates converge to similar values with increasing depth and age in the sediment.

Sulphate reduction rates have been measured experimentally, and sulphate-reducing microorganisms have been quantified in marine sediments from the high Arctic, the Baltic Sea and the Black Sea ${ }^{68-73}$. In the uppermost bioturbated sediment, the mean cell-specific rate of sulphate reduction was around $0.1 \mathrm{fmol} \mathrm{SO}_{4}^{2-} \mathrm{cell}^{-1} \mathrm{~d}^{-1}$ 


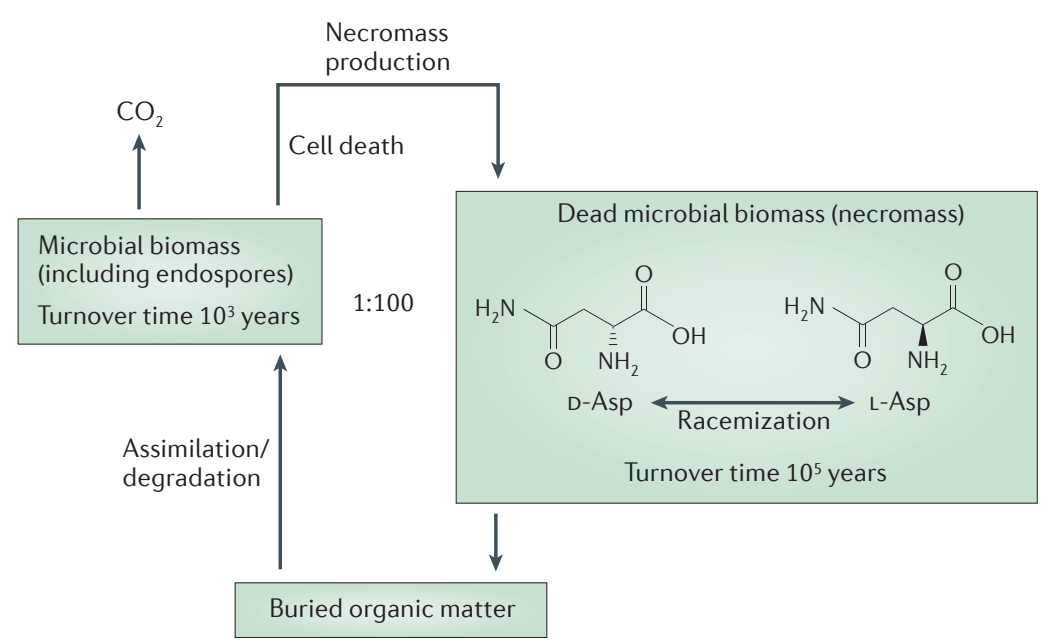

Figure 2 | Principle of D:L amino acid racemization model for the calculation of microbial turnover in subsurface sediments. The turnover of total hydrolysable amino acids in microbial necromass is calculated from the dynamic ratio of D:L aspartate (Asp) and from other analysed parameters. The production of necromass from living cells is in quasi steady state with the further turnover of necromass by microbial assimilation and degradation. The mean turnover time of living microbial biomass will thus be equal to the turnover time of necromass divided by the ratio between living and dead biomass (after Lomstein et al. ${ }^{65}$ ). requirement for the aerobes would be consistent with the greater cost of biosynthesis ${ }^{75}$, and potentially increased rates of oxidative damage, under aerobic conditions.

These two examples raise the important question of whether the mean cell-specific rates of microbial respiration in different subsurface environments converge towards a general minimum level, the basal power requirement as defined above. In the following section we use data for dissimilatory sulphate reduction and marine sediments to address this question.

The range of metabolic rates. The cell carbon turnover rates for sulphate-reducing microorganisms from pure cultures and surficial or deep marine sediments are compared in FIG. 4 for temperatures ranging from $-5^{\circ} \mathrm{C}$ to $+20^{\circ} \mathrm{C}$. Pure cultures of sulphate-reducing bacteria have doubling times that vary from less than 1 day to several weeks ${ }^{76-79}$. In the most active surface layers of marine sediment, where fresh deposition of organic matter, burrowing activity of benthic invertebrates and grazing on the bacterial communities stimulate active microbial growth, the calculated mean doubling times are around 1 year ${ }^{68-73}$. This shows that the growth rate in even very active natural communities is 100 -fold lower than it is in laboratory cultures. Extremely slow growth is thus not such a unique property of the deep biosphere, although it is a defining characteristic of life in that realm. Rather, it appears to be widespread among natural communities and might be one of the reasons for the difficulty in isolating organisms into laboratory culture. In deep sub-seafloor sediments, the calculations based on cellspecific sulphate reduction rates or the D:L amino acid racemization model independently yield mean turnover times of cell biomass of a few hundred to a few thousand years: that is, 100-1,000 times slower than in surface sediments ${ }^{42,65-69}$ (FIG. 4). In comparing these values, it should be borne in mind that the calculations of cellspecific rates are based on several assumptions that have not been well tested. These calculations assume that $10 \%$ of all cells in the sulphate zone are sulphate reducers. If the percentage is lower, then the cell-specific rates of sulphate reduction are higher. The calculation also assumes growth yields comparable to slow-growing laboratory cultures. If the growth yields in natural populations are lower, the carbon turnover times would be correspondingly longer. However the D:L amino acid racemization model yields an independent estimate of cell turnover in Peru margin sediments that is consistent with growth yields observed for slow-growing pure cultures $^{65}$. Although this observation needs further testing, it indicates that the growth yield might not approach zero when cell turnover becomes extremely slow in these subsurface communities. This is in contrast to observed trends in pure cultures under starvation conditions and shows the need for caution when extrapolating to natural communities thriving under low energy flux.

Calculations similar to those in FIG. 4 have been made for several other metabolic processes and environments ${ }^{49,56,64,67,80,81}$ and were reviewed by Price and Sowers ${ }^{82}$. Such published data show both higher and lower values than those in FIG. 4, and scatter over many orders of 


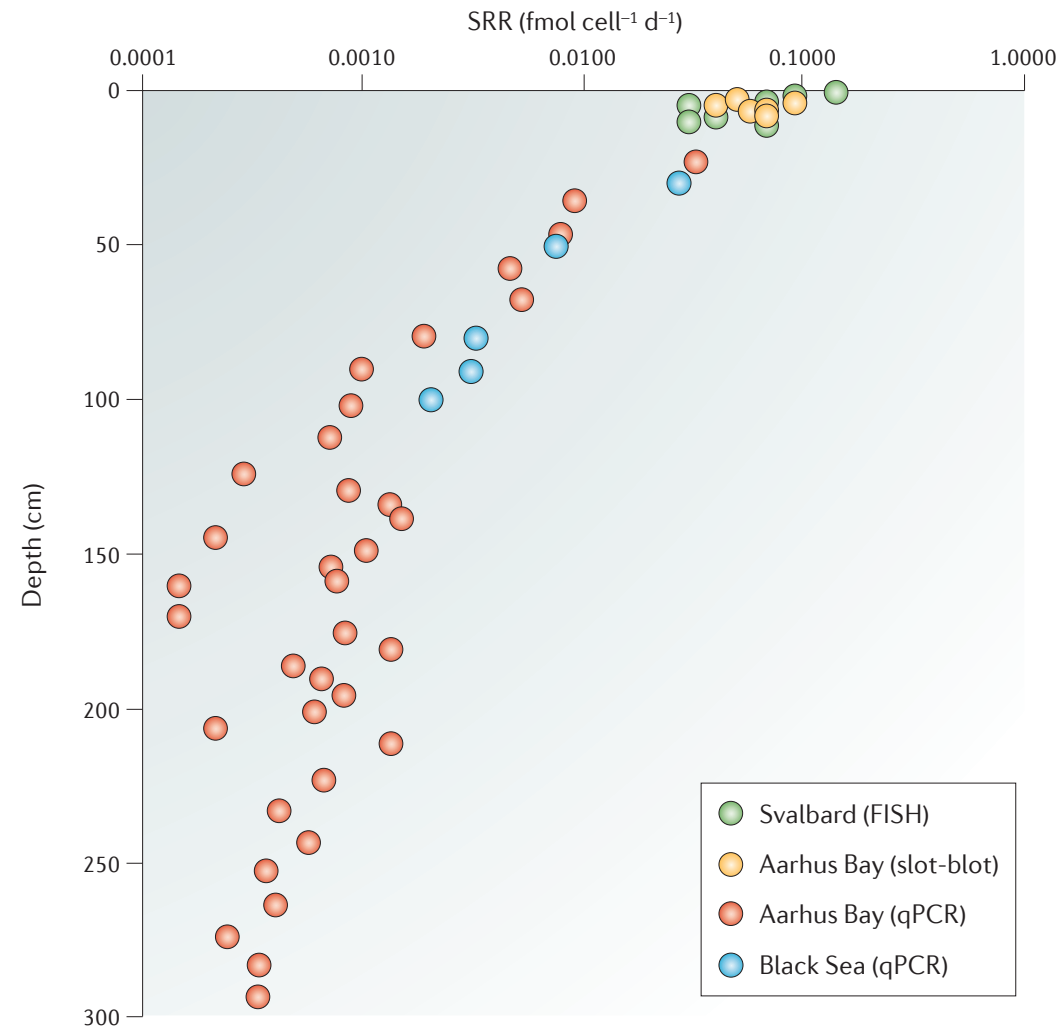

Figure 3 | Mean cell-specific rates of sulphate reduction in marine sediments from three different geographical regions. The rates were calculated by dividing the bulk rates of sulphate reduction by the total number of sulphate reducers. The mean cell-specific respiration drops 100-1,000-fold between the surface sediment and $300 \mathrm{~cm}$ subsurface. In all examples, the bulk rates of sulphate reduction were measured by the ${ }^{35} \mathrm{~S}$ tracer technique. Sulphate reducing microorganisms were directly quantified at the same depths by DNA- or RNA-based techniques as indicated. Green symbols: Arctic fjord sediment of Svalbard, $79^{\circ} \mathrm{N}$, at $200 \mathrm{~m}$ water depth, fluorescence in situ hybridization (FISH) counts of hybridized cells ${ }^{72}$. Yellow symbols: Aarhus Bay, Baltic Sea at $16 \mathrm{~m}$ water depth, slot-blot hybridization of ribosomal RNA ${ }^{130}$. Red symbols: Aarhus Bay, quantitative PCR (qPCR) of $d s r A$ genes ${ }^{69,70}$. Blue symbols: Black Sea sulphidic zone at $1,000 \mathrm{~m}$ water depth, qPCR of dsrA genes ${ }^{68,71}$.
The biological implications of the extremely low metabolic rates calculated for subsurface sediments are profound. A respiration rate of $10^{-4}-10^{-3} \mathrm{fmol} \mathrm{SO}_{4}{ }^{2-}$ cell ${ }^{-1} \mathrm{~d}^{-1}$ is equal to $10^{-23}-10^{-24} \mathrm{~mol} \mathrm{SO}_{4}^{2-}$ cell $^{-1} \mathrm{~s}^{-1}$. As 1 mol comprises $6 \times 10^{23}$ ions (Avogadro's number), the sulphate reducers respire on average 1 sulphate ion per cell per second. Well-known cellular functions such as flagellar motility are not possible at such a metabolic rate; the rotation of a single bacterial flagellum in $E$. coli requires 1,200 protons per revolution or $10^{4}-10^{5}$ protons per second ${ }^{83}$, so at 1 sulphate ion per second, a single revolution of a flagellum would last several minutes. Without flagellar motility, bacteria can move randomly by Brownian motion that in porous sediments has an effective diffusion coefficient of $10^{-9} \mathrm{~m}^{2} \mathrm{~s}^{-1}$ (REF. 84). Over 1 million years, such random motion will lead to a mean displacement of only 6 metres (diffusion time, $t=\pi L^{2} / 4 D_{s}$, in which $L$ is the mean displacement and $D_{s}$ is the effective diffusion coefficient of cells). For impermeable, non-advective sediments, the lack of flagellar propulsion thus appears to provide a strong barrier to genetic exchange with the surface world by whole cells.

Dormancy or alternative energy sources. The above estimates of mean rates of carbon turnover tacitly assume that the entire microbial community is active. Yet, hypothetically, only a fraction of the cells might be active at any time while the rest are in a dormant state ${ }^{85}$. The most durable dormancy known is endospore formation in bacteria. Recent quantification of endospores in deep, million-year-old sediments ${ }^{65}$ has shown that spores can be as abundant as vegetative cells but that the fraction of spores does not systematically increase with depth into the oldest and most energy-deprived sediment. In environments that change over time, dormancy and, in particular, spore formation represent a bet-hedging strategy that can be used during periods of environmental stress ${ }^{85}$. Dormancy increases the chance that a fraction of the population will survive inclement periods. However, in environments that are extremely stable over millions of years and in which the available energy flux decreases slowly and steadily with time, dormancy would arguably be a dead end. The transition between dormancy and the active, vegetative state has an energetic cost, and spore-forming microorganisms could therefore be at a disadvantage owing to the extra energy demand for germination and repair of accumulated damage to key macromolecules such as DNA. In microbial communities locked into permafrost soils for hundreds of thousands of years, long-term survival appears to select against spore formers ${ }^{86}$. Thus, although bacterial spores are often as abundant as vegetative cells in the deep biosphere ${ }^{65}$ their potential role for the maintenance of the microbial communities under permanent low energy flux is unclear.

There are several lines of evidence suggesting that, apart from bacterial endospores, the deep biosphere is inhabited primarily by viable and active cells ${ }^{87}$. Quantification of subsurface cells with FISH, CARDFISH or qPCR has characterized a large fraction of the total cell numbers and shown that the cells have 


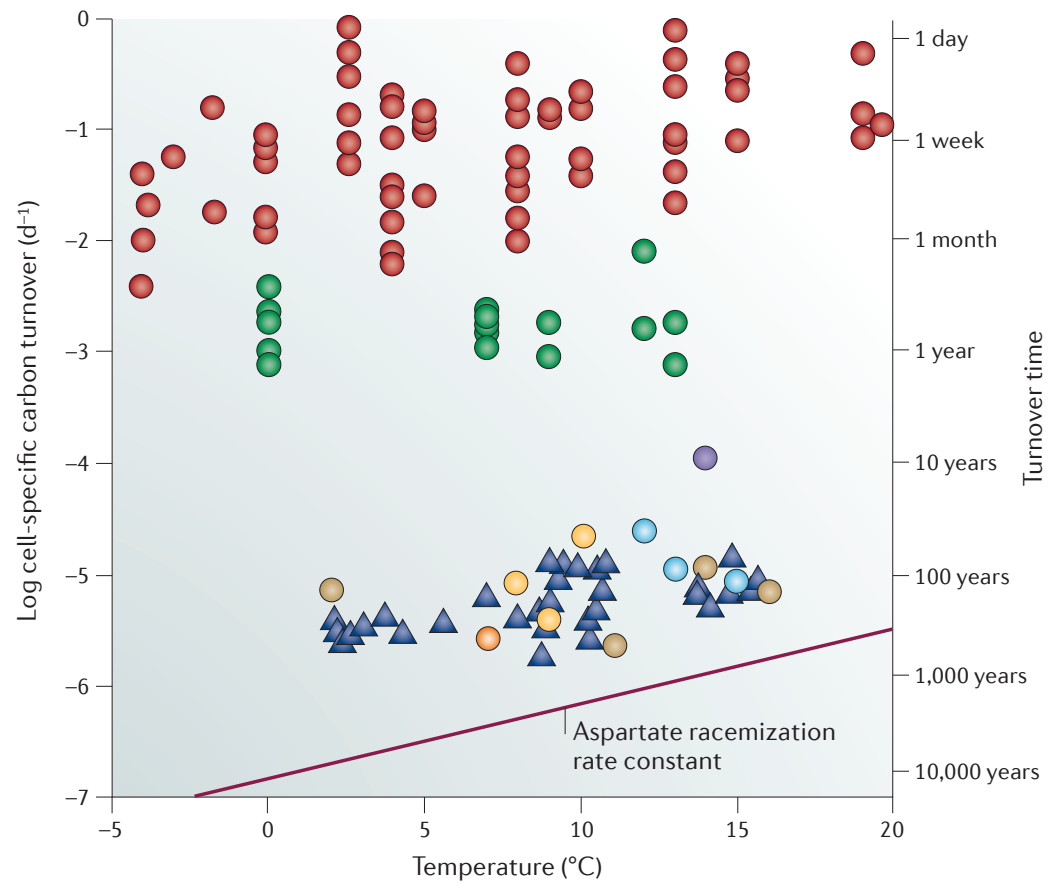

$\begin{array}{ll}\text { Pure cultures of SRB } & \bigcirc \text { Eastern tropical Pacific } \\ \text { Marine surface sediments } & \bigcirc \text { Peru shelf } \\ \text { Aarhus Bay } & \bigcirc \text { Peru shelf } \\ \text { Eastern tropical Pacific and Peru shelf } & \triangle \text { Peru shelf (D:L racemization model) }\end{array}$

Figure 4 | Mean cell-specific carbon turnover in marine sulphate-reducing microorganisms. The rates were calculated as mol assimilated $C$ per mol cell $C$ per day (left scale) as a function of temperature. From the data on cell carbon turnover per day we calculated the corresponding turnover time (right scale). For the pure cultures this corresponds to the actual generation times. For the deep sediment bacteria we assume that the carbon turnover leads to growth and cell division, although this is not directly implied. The red line indicates the racemization rate constant for aspartate ${ }^{100}$. The graph compares pure cultures (red circles), active surface sediments (green circles) and deep subsurface sediments (other symbols). Pure culture data are based on published growth rate constants. Carbon assimilation rates in sediment communities are based on an estimated growth yield of $2 \mathrm{~g}$ cell carbon per mol substrate (acetate) consumed and a mean biomass of $65 \mathrm{fg} \mathrm{C}$ cell $^{-1}$ (REF. 65). Carbon turnover rates in subsurface sediments were also determined by the D:L amino acid racemization model (dark blue triangles), which directly estimates cellular carbon turnover. Data were compiled and recalculated from: REFS 76-79 (red circles); REFS 68-72,130 (green circles); REFS 67-69 (yellow circles); REF. 67 (tan circles); unpublished data from the Ocean Drilling Program (ODP) and H. Røy et al. (orange circle); unpublished data from the ODP and J. Kallmeyer et al. (light blue circles); REF. 42 (purple circle); and REF. 65 (dark blue triangles). SRB, sulphate-reducing bacteria.

Depurination

An alteration of DNA in which

the purine base (adenine or guanine) is lost from the

deoxyribose sugar by hydrolysis of the $\beta-N$-glycosidic link between them. sufficiently intact RNA and DNA to hybridize with probes and primers ${ }^{67,80,88}$. Experiments with the addition of stable isotope-labelled substrates to subsurface sediment and probing of many individual cells after month-long incubation indicate that a large fraction of the cells are induced to actively assimilate substrate ${ }^{89}$. Analysis with a nano-scale secondary ion mass spectrometer (nano-SIMS) provided estimated assimilation rates on the order of $0.01 \mathrm{fmol}$ cell ${ }^{-1} \mathrm{~d}^{-1}$ for ${ }^{13} \mathrm{C}$ and ${ }^{15} \mathrm{~N}$ labelled substrates ${ }^{89}$. Such observations are consistent with a deep biosphere inhabited by cells that are not dormant or dead but that instead subsist in a viable state with extremely low metabolic rate.
The existence of cryptic (heretofore uncharacterized) energy sources might present an alternative to the extremely low rates of cellular metabolism calculated here. The neglect of such sources in our calculations would lead to an underestimation of the mean cellspecific energy flux and thus of the basal power requirement of bacteria and archaea. However, the inorganic and organic geochemistry has been carefully explored in several of the sediment sites in which the deep biosphere was studied ${ }^{56,61,90,91}$. In those low-energy sediments, the organic material originally deposited on the sea floor and buried to great depth over millions of years appears to be the main source of carbon and energy for the deep biosphere. However, there could be alternative types of energy metabolism or rock-fluid-microorganism interactions that were previously unknown. As an example, sulphate reduction coupled to ammonium oxidation has been proposed as a thermodynamically feasible pathway that has a Gibbs free energy of reaction of -10 to $-20 \mathrm{~kJ} \mathrm{~mol}^{-1} \mathrm{SO}_{4}^{2-}$ in sub-seafloor sediments ${ }^{92}$. Another example is the high-energy radiation from natural radioisotopes (such as ${ }^{40} \mathrm{~K},{ }^{232} \mathrm{Th}$ and ${ }^{238} \mathrm{U}$ ) buried with the sediment, which produces $\mathrm{H}_{2}$ and oxygen radicals by the radiolytic cleavage of water molecules ${ }^{93}$. A theoretical calculation of the potential for this mode of $\mathrm{H}_{2}$ formation shows that it could become an important contributor to energy flux in oceanic regions where organic-fuelled respiration rates are exceedingly low ${ }^{94}$.

Controls on metabolic rates. In deep sediment cores, cell counts indicate that the community size remains essentially constant over depth intervals corresponding to thousands to millions of years, at a level where the available energy flux presumably just covers the basal power requirement for long-term survival of the cells. Under such extremely stable conditions, what is the mean age of the cells? Ageing has been suggested to take place in bacterial populations as a result of the gradual accumulation of non-genetic damage, such as proteins that become oxidized and lose function. If there is an asymmetrical transfer of old and new cell material during binary fission, such ageing can lead to a differentiation of daughter cells with different fitness ${ }^{95}$. However, there is no inherent ageing process known for individual bacterial and archaeal cells that would limit their potential age. Cells could theoretically have near-zero growth over thousands of years and simply turn over cell components in a highly efficient manner. Spontaneous racemization of amino acids and depurination of nucleic acids impose a lower bound on the necessary rates of molecular repair or re-synthesis. Relative to these limits, the deep biosphere turnover rate of cell carbon at $0-15^{\circ} \mathrm{C}, 10^{-6}-10^{-5} \mathrm{~d}^{-1}$ (FIC. 4), is tenfold faster than that required to offset racemization of amino acids (aspartate), $10^{-7}-10^{-6} \mathrm{~d}^{-1}$ (REFS 65,66), and perhaps even 1,000 -fold faster than that required to offset DNA depurination $^{82}$. The turnover of biomass above and beyond these minimum required rates might reflect growth but, given the apparent steady state in population size with depth, the rate of such growth at steady state cannot exceed the rate of mortality. 
What, then, controls mortality? It remains unknown whether eukaryotic bacterial grazers have a role in the deep subsurface. Combined DNA- and RNA-based clone libraries from deep subsurface sediments showed mostly fungal sequences of Basidiomycetes but did not detect protozoan grazers ${ }^{96}$. The recovery of both RNA and DNA of anaerobic fungi suggests that they are metabolically active and might complement bacteria and archaea in the utilization and recycling of nutrients. Viruses were recently shown to be present in the deep subsurface at numbers decreasing from $10^{8}-10^{10} \mathrm{~cm}^{-3}$ at the sediment surface ${ }^{97}$ to $10^{6}-10^{8} \mathrm{~cm}^{-3}$ at $100-400 \mathrm{~m}$ below the sea floor ${ }^{98,99}$. Middelboe et al. ${ }^{99}$ suggested that most of these viruses are inactive but persistent and are somehow protected and only slowly decaying. However, by cultivating deep sediment bacteria, Engelhardt et al..$^{98}$ found that most strains harboured inducible prophages, which demonstrates the presence of functional viruses. Virus-induced mortality in the deep biosphere remains unexplored.

\section{Are there low-energy specialists?}

The persistent march of evolution allows us to think of every ecological niche as being occupied by organisms that are finely adapted to its specific conditions. Certainly, there must be physiological attributes that leave some organisms better suited than others to survive with low energy flux. But is it possible to adapt and evolve specifically with starvation as a selection pressure? The GASP phenotype that consistently arises in extended stationary phase cultures ${ }^{9,10}$ is tempting as an example of exactly such behaviour. But it is worth recalling that the 'G' in GASP stands for growth and that these systems are characterized by dynamic overturn in the population and its genetic material ${ }^{10,15}$. There is therefore potential to acquire and transmit, at considerable rates, genetic mutations that confer the advantage in extended stationary phase $\mathrm{e}^{12-14}$. For genetic adaptations to arise that are specific to the selection pressure of low energy flux is problematic for two reasons. First, slow rates of biomass turnover provide minimal basis for the introduction and propagation of beneficial mutations, and only if that turnover represents whole cells rather than molecules within cells. Second, the low-energy environments studied thus far could largely be considered 'dead ends' that seemingly provide no mechanism by which a population of survivors can once again see conditions favourable to growth. For natural selection based on energy starvation to be realistic would require circumstances that mitigate both of these challenges. One alternative is that traits acquired in adapting to other settings, or random mutations incurred during the initial colonization of ultimately low energy environments, fortuitously confer enhanced capability to survive starvation.

\section{Traits for coping with low energy flux?}

Biosynthetic rate and cost. Biosynthesis is energetically expensive. Stouthammer's calculations suggest that polymerization reactions are particularly costly and that by virtue of the large protein component in cells, protein synthesis constitutes the largest single cost ${ }^{21,23}$. Although attrition (and, presumably, repair or replacement) of biomolecules at low rates is unavoidable $e^{100,101}$, organisms that minimize the rate of biosynthesis above and beyond this basal minimum will significantly decrease their energy requirements. The rate of overturn (death/regrowth) of whole cells, versus repair or replacement of molecules within cells, is a first-order control on 'excess' biosynthetic cost. Metabolic regulation, with continual synthesis and breakdown of proteins, will be similarly expensive - and essentially superfluous in environments where conditions change little over long durations. Simple and relatively unregulated metabolisms might be the most efficient. Beyond the biosynthetic rate, the cost of synthesis might conceivably also vary, and would certainly matter. A rigorous thermodynamic analysis shows that the theoretical minimum biosynthetic cost of whole cells is nearly 13 -fold lower in reducing versus oxic environments ${ }^{75}$. For this difference to be realized would require alternative (less energyintensive) biosynthetic pathways, such as the reductive acetyl CoA pathway rather than the RuBisCO pathway for $\mathrm{CO}_{2}$ assimilation ${ }^{102}$. This might not be feasible in all cases (recognizing in particular that part of the energetic cost of polymerization is to ensure sequence fidelity), but it does suggest an avenue by which maintenance costs might be lowered.

Energy conservation. Thermodynamics dictate that the process of energy capture and storage must involve some loss of the energy of catabolism to heat ${ }^{103,104}$, but the degree of such a loss can depend significantly on biochemical specifics. It is also known that trans-membrane ion gradients - the intermediate mode of energy storage on the path to ATP synthesis ${ }^{105}$ - leak over time ${ }^{106}$, resulting in loss of hard-won catabolic energy capture. Because the membrane must remain charged at a minimum potential in order to support ATP synthesis, a certain rate of energy loss is unavoidable. This loss could in principle place a hard lower limit on the energy flux needed for survival that could, depending on the leakage rate, significantly exceed the energy required to support a cell's cohort of biomolecules against degradation. The loss could be minimized either by the use of membranes that are less permeable to ion leakage or by the utilization of different ions in chemiosmotic energy transduction ${ }^{106,107}$. For example, sodium ions, which are widely used by both bacteria and archaea, have trans-membrane diffusion rates $10^{2}$ - to $10^{3}$-fold lower than protons ${ }^{106}$, and some archaea have been shown to have a very energy-efficient mixed $\mathrm{H}^{+} / \mathrm{Na}^{+}$driven ATP synthase ${ }^{108}$.

Are archaea better suited for starvation than bacteria? As most subsurface microorganisms have no cultivated relatives, it is difficult to infer a shift in physiological characteristics from a shift in predominant phylotypes ${ }^{109,110}$. Most notable is a relative increase in the abundance of archaea relative to bacteria. Early reports provided divergent evidence for their relative abundance, ranging from insignificance to total dominance of the archaea ${ }^{61,67,88}$. More recent reports provide a more 
balanced picture, but the overall trend is towards a relatively higher frequency of archaea in the energy-starved subsurface than in surface environments ${ }^{111}$. This trend is observed both in sediments with sulphate reduction and with methanogenesis as the terminal mineralization process, and indicates that archaea occupy a broad range of metabolic functions that are generally ascribed to the bacteria in non-extreme environments ${ }^{61,112,113}$.

Archaea have mostly been known to dominate over bacteria in environments of chronic energy stress, such as high temperature, high salinity and low $\mathrm{pH}^{114}$. The rationale for their abundance under low energy flux is not clear, but it could be related to distinct cell properties such as the permeability of the cell membrane. Although microorganisms have a certain ability to control the fluidity and permeability of their cytoplasmic membrane, the molecular lipid composition of the archaeal membrane means that archaeal cells have much lower permeability to ions, and thereby lower energy loss from the charged membrane, than bacterial cells ${ }^{107,115}$. The archaea could thereby be able to maintain energy transduction at lower energy flux than the bacteria through proton or sodium pumping. Interestingly, deep-sea archaea might also save energy by recycling membrane lipids between growing cells and the surrounding sediment ${ }^{116}$.

\section{Outlook: important areas for future research}

Progress in field, laboratory and theoretical studies will all serve to advance our understanding of life at low energy flux. Deep subsurface ecosystems reflect the results of experiments performed by nature over timescales that are completely inaccessible in the laboratory. Our ability to read and interpret these results depends on accessing such environments using advanced coring technology and appropriate contamination controls, and perhaps also on identifying more easily accessible shallow subsurface environments in which microbial communities have higher densities but might exhibit similar characteristics. Example cases in which shallow coastal sediments reflect significant energy limitation within a few metres of the surface ${ }^{68,117}$ suggest that many such environments could be suitable for this focus. For studies in these environments, improvements are needed in the methods used to distinguish active and inactive cells, to determine cell size and growth yield, to measure process rates at very low levels and to characterize the nature of carbon turnover (whether of whole cells or molecules therein).

In the laboratory, efforts should be made to bring into culture those organisms that dominate low-energy settings but have no close relatives available in pure culture ${ }^{118,119}$. Inherently slow growth, should it be a characteristic of natural populations, will limit this possibility using traditional methods, but single-cell and microanalytical techniques could overcome some of these limitations. Changes to traditional culture methods that focus on sustaining organisms under low energy flux or extremely slow growth will also be important, and retentostat and microfluidic chemostat approaches represent a step in the right direction.

'Omic' approaches could help to bridge the current gap between the laboratory and the field. Comparative metagenomics can help to identify characteristic differences between surface and subsurface populations, and potentially link these differences to metabolic or physiological capabilities. Single-cell genomics holds similar promise for understanding the metabolic potential of organisms that dominate the deep biosphere but resist efforts at culturing ${ }^{120}$. Application of transcriptomic and proteomic techniques might help to reveal whether cells can actively regulate a transition into physiological states that are suited for low energy flux. Finally, theoretical studies, supported by experimental data, are needed to understand the minimum energy and nutrient requirements for long-term sustainability of bacterial and archaeal cells over hundreds to thousands of years.

Far from being the specific province of deep sedimentary systems, low energy flux is probably characteristic of broad-ranging environments, including the volumetrically vast potential habitat represented by terrestrial and oceanic crust, as well as in subsurface environments beyond Earth. Progress in characterizing life's basal energy requirements and their dependence on the physicochemical environment, and in identifying the adaptations and attributes that suit organisms to life under low energy flux, is crucial for understanding the biological potential of these largely uncharacterized environments.
1. Whitman, W. B., Coleman, D. C. \& Wiebe, W. J. Prokaryotes: the unseen majority. Proc. Natl Acad. Sci. USA 95, 6578-6583 (1998).

An early effort to estimate the magnitude and extent of the deep biosphere.

2. Kallmeyer, J., Pockalny, R., Adhikari, R. R., Smith, D. C. \& D'Hondt, S. Global distribution of microbial abundance and biomass in subseafloor sediment. Proc. Natl Acad. Sci. USA 109, 16213-16216 (2012).

3. DeLong, J. P., Okie, J. G., Mosesa, M. E., Siblyd, R. M. \& Brown, J. H. Shifts in metabolic scaling, production, and efficiency across major evolutionary transitions of life. Proc. Natl Acad. Sci. USA 107, 12941-12945 (2010).

4. Kempes, C., Dutkiewicz, S. \& Follows, M. Growth metabolic partitioning, and the size of microorganisms. Proc. Natl Acad. Sci. USA 109, 495-500 (2012).

5. Makarieva, A. M., Gorshkov, V. G. \& Li, B.-L. Energetics of the smallest: do bacteria breathe at the same rate as whales? Proc. R. Soc. B 272, 2219-2224 (2005).

6. Makarieva, A. M. et al. Mean mass-specific metabolic rates are strikingly similar across life's major domains: evidence for life's metabolic optimum. Proc. Natl Acad. Sci. USA 105, 16994-16999 (2008).
7. Mason, M. M. A comparison of the maximal growth rates of various bacteria under optimal conditions. J. Bacteriol. 29, 103-110 (1935).

8. Finkel, S. E. Long-term survival during stationary phase: evolution and the GASP phenotype. Nature Rev. Microbiol. 4, 113-120 (2006).

An excellent review of extended stationary phase and the GASP phenotype.

9. Zambrano, M. M., Siegele, D. A., Almiron, M. Tormo, A. \& Kolter, R. Microbial competition: E. coli mutants that take over stationary phase cultures. Science 259, 1757-1760 (1993).

10. Finkel, S. E. \& Kolter, R. Evolution of microbial diversity during prolonged starvation. Proc. Natl Acad. Sci. USA 96 4023-4027 (1999).

11. Steinhaus, E. A. \& Birkeland, J. M. Studies on the life and death of bacteria. I. The senescent phase in aging cultures and the probable mechanisms invovled. J. Bacteriol. 38, 249-261 (1939).

12. Zinser, E. R. \& Kolter, R. E. coli evolution during stationary phase. Res. Microbiol. 155, 328-336 (2004).

13. Zinser, E. R. \& Kolter, R. Mutations enhancing amino acid catabolism confer a growth advantage in stationary phase. J. Bacteriol. 181, 5800-5807 (1999).
14. Zinser, E. R. \& Kolter, R. Prolonged stationary phase incubation selects for Irp mutants in E. coli K-12. J. Bacteriol. 182, 4361-4365 (2000).

15. Farrell, M. J. \& Finkel, S. E. The growth advantage in stationary phase phenotype conferred by rpoS mutations is dependent on the $\mathrm{pH}$ and nutrient environment. J. Bacteriol. 185, 7044-7052 (2003).

16. Røy, H. et al. Aerobic microbial respiration in 86-million-year-old deep-sea red clay. Science 336 922-925 (2012).

The observation of aerobic microbial respiration in 86-million-year-old sediments in one of Earth's most oligotrophic settings.

17. Russell, J. B. ¿ Cook, G. M. Energetics of bacterial growth: balance of anabolic and catabolic reactions. Microbiol. Rev. 59, 48-62 (1995).

An excellent overview of energy metabolism, maintenance energy and energy spilling.

18. Tempest, D. W. $\&$ Neijssel, O. M. The status of $Y_{\text {ATP }}$ and maintenance energy as biologically interpretable phenomena. Annu. Rev. Microbiol. 38, 459-486 (1984).

19. van Bodegom, P. Microbial maintenance: a critical review on its quantification. Microb. Ecol. 53, 513-523 (2007). 
20. Bauchop, T. \& Eldsen, S. R. The growth of microorganisms in relation to their energy supply. J. Gen. Microbiol. 23, 457-469 (1960).

21. Stouthamer, A. H. A theoretical study on the amount of ATP required for synthesis of microbial cell material. Antonie Leeuwenhoek 39, 545-565 (1973).

22. Stouthamer, A. H. \& Bettenhaussen, C. W. Utilizatoin of energy for growth and maintenance in continuous and batch cultures of microorganisms. Biochim. Biophys. Acta 301, 53-70 (1973).

23. Stouthamer, A. H. in International Review of Biochemistry and Microbial Biochemistry Vol. 21 (ed. Quayle, J. R.) 1-47 (Univ. Park Press, 1979)

24. Pirt, S. J. The maintenance energy of bacteria in growing cultures. Proc. R. Soc. B 163, 224-231 (1965).

25. Pirt, S. J. Maintenance energy: a general model for energy-limited and energy-sufficient growth. Arch. Microbiol. 133, 300-302 (1982).

26. Herbert, D., Elsworth, R. \& Telling, R. C. The continuous culture of bacterial: a theoretical and experimental study. J. Gen. Microbiol. 14, 601-622 (1956).

27. Novick, A. \& Szilard, L. Description of the chemostat. Science 112, 715-716 (1950)

28. Tijhuis, L., van Loosdrecht, M. C. M. \& Heijnen, J. J. A thermodynamically based correlation for maintenance Gibbs energy requirements in aerobic and anaerobic chemotrophic growth. Biotechnol. Bioengineer. 42, 509-519 (1993).

29. Morita, R. Bacteria in Oligotrophic Environments (Chapman \& Hall, 1997).

30. Morita, R. Is $\mathrm{H}_{2}$ the universal energy source for longterm survival? Microb. Ecol. 38, 307-320 (2000).

31. Scholten, J. C. M. \& Conrad, R. Energetics of syntrophic propionate oxidation in defined batch and chemostat cocultures. Appl. Environ. Microbiol. 66 2934-2942 (2000).

32. Tappe, W. et al. Maintenance energy demand and starvation recovery dynamics of Nitrosomonas europaea and Nitrobacter winogradskyi cultivated in a retentostat with complete biomass retention. Appl. Environ. Microbiol. 65, 2471-2477 (1999).

33. Niejssel, O. M. \& Tempest, D. W. The role of energyspilling reactions in the growth of Klebsiella aerogenes NCTC 418 in aerobic chemostat culture. Arch. Microbiol. 110, 305-311 (1976)

34. Cook, G. M. \& Russell, J. B. Energy spilling reactions of Streptococcus bovis and resistance of its membrane to proton conductance. Appl. Environ. Microbiol. 60 1942-1948 (1994).

35. Russell, J. B. \& Strobel, H. J. ATPase-dependent energy spilling by the ruminal bacterium, Streptococcus bovis. Arch. Microbiol. 153, 378-383 (1990).

36. Groisman, A et al. A microfluidic chemostat for experiments with bacterial and yeast cells. Nature Methods 2, 685-689 (2005).

37. Lee, K. S., Boccazzi, P., Sinskey, A. J. \& Ram, R. J. Microfluidic chemostat and turbidostat with flow rate, oxygen, and temperature control for dynamic continuous culture. Lab. Chip 11, 1730-1739 (2011)

38. Lin, B., Westerhoff, H. V. \& Röling, W. F. M. How Geobacteraceae may dominate subsurface biodegradation: physiology of Geobacter metallireducens in slow-growth habitat-simulating retentostats. Environ. Microbiol. 11, 2425-2433 (2009).

39. Tappe, W., Tomaschewski, C., Rittershaus, S. ¿ Groeneweg, J. Cultivation of nitrifying bacteria in the retentostat, a simple fermenter with internal biomass retention. FEMS Microbiol. Ecol. 19, 47-52 (1996).

40. Girguis, P. R., Cozen, A. E. \& DeLong, E. F. Growth and population dynamics of anaerobic methane-oxidizing archaea and sulfate-reducing bacteria in a continuousflow bioreactor. Appl. Environ. Microbiol. 71 3725-3733 (2005).

41. Imachi, H. et al. Cultivation of methanogenic community from subseafloor sediments using a continuous-flow bioreactor. ISME J. 5, 1913-1925 (2011).

42. Parkes, R. J. et al. Bacterial biomass and activity in deep sediment. Layers from the Peru Margin [and Discussion]. Phil. Trans. R. Soc. Lond. A 331, 139-153 (1990).

One of the earliest demonstrations of the presence of active microorganisms in deep sediments.

43. Joye, S. B. et al. The anaerobic oxidation of methane and sulfate reduction in sediments from Gulf of Mexico cold seeps. Chem. Geol. 205, 219-238 (2004).

44. Treude, T. et al. Anaerobic oxidation of methane and sulfate reduction along the Chilean continental margin. Geochim. Cosmochim. Acta 69, 2767-2779 (2005)

45. Parkes, R. et al. Deep sub-seafloor prokaryotes stimulated at interfaces over geological time. Nature 436, 390-394 (2005)

46. Boudreau, B. P. Diagenetic Models and their Implementation (Springer, 1997).

47. Arndt, S., Hetzel, A. \& Brumsack, H. J. Evolution of organic matter degradation in Cretaceous black shales inferred from authigenic barite: a reaction-transport model. Geochim. Cosmochim. Acta 73, 2000-2022 (2009)

48. Wang, G., Spivack, A. J., Rutherford, S., Manorc, U. \& D'Hondt, S. Quantification of co-occurring reaction rates in deep subseafloor sediments. Geochim. Cosmochim. Acta 72, 3479-3488 (2008).

49. Phelps, T. J., Murphy, E. M., Pfiffner, M. \& White, D. C. Factors influencing the abundance and metabolic capacities of microorganisms in eastern coastal-plain sediments. Microb. Ecol. 28, 335-349 (1994).

50. Wheat, C. G. \& Fisher, A. T. Seawater recharge along an eastern bounding fault in Middle Valley, northern Juan de Fuca Ridge. Geophys. Res. Lett. 34, L20602 (2007).

51. Chapelle, F. H. \& Lovley, D. R. Rates of microbial metabolism in deep coastal plain aquifers. Appl. Environ. Microbiol. 56, 1865-1874 (1990).

52. Kallmeyer, J. Detection and quantification of microbial cells in subsurface sediments. Adv. Appl. Microbiol. 76, 79-103 (2011).

53. Morono, Y., Terada, T., Masui, N. \& Inagaki, F. Discriminative detection and enumeration of microbial life in marine subsurface sediments. ISME J. 3, 503-511 (2009).

54. Kallmeyer, J., Smith, D. C., Spivack, A. J. \& D'Hondt, S. New cell extraction procedure applied to deep subsurface sediments. Limnol. Oceanogr. Methods 6, 236-245 (2008)

55. Parkes, R. J., Cragg, B. A. \& Wellsbury, P. Recent studies on bacterial populations and processes in subseafloor sediments: a review. Hydrogeol. Rev. 8 , 11-28 (2000)

56. D'Hondt, S. et al. Subseafloor sedimentary life in the South Pacific Gyre. Proc. Natl Acad. Sci. USA 106 11651-11656 (2009)

57. Cockell, C. S. et al. Impact disruption and recovery of the deep subsurface biosphere. Astrobiology 12 231-246 (2012).

58. Amann, R. I. Fluorescently labeled, ribosomal-RNAtargeted oligonucleotide probes in the study of microbial ecology. Mol. Ecol. 4, 543-553 (1995)

59. Wagner, M. et al. Functional marker genes for identification of sulfate-reducing prokaryotes. Methods Enzymol. 397, 469-489 (2005).

60. Teske, A. \& Sørensen, K. B. Uncultured archaea in deep marine subsurface sediments: have we caught them all? ISME J. 2, 3-8 (2008)

61. Lipp, J. S., Morono, Y., Inagaki, F. \& Hinrichs, K.-U. Significant contribution of Archaea to extant biomass in marine subsurface sediments. Nature 454, 991-994 (2008)

62. Logemann, J. et al. A laboratory experiment of intact polar lipid degradation in sandy sediments. Biogeosciences 8, 2547-2560 (2011).

63. Schouten, S., Middleburg, J. J., Hopmans, E. C. \& Damsté, J. S. S. Fossilization and degradation of intact polar lipids in deep subsurface sediments: a theoretical approach. Geochim. Cosmochim. Acta 74 , 3806-3814 (2010).

64. D'Hondt, S., Rutherford, S. \& Spivack, A. J. Metabolic activity of subsurface life in deep-sea sediments. Science 295, 2067-2070 (2002) An early observation of low process rates in deep sediments.

65. Lomstein, B. A. et al. Endospore abundance, microbial growth and necromass turnover in deep sub-seafloor sediment. Nature 484, 101-104 (2012).

66. Bada, J. L. Racemization of amino acids in nature. Interdiscip. Sci. Rev. 7, 30-46 (1982)

67. Biddle, J. F. et. al. Heterotrophic Archaea dominate sedimentary subsurface ecosystems off Peru. Proc. Natl Acad. Sci. USA 103, 3846-3851 (2006).

68. Holmkvist, L. et al. Sulfate reduction below the sulfatemethane transition in Black Sea sediments. Deep Sea Res. Part I Oceonogr. Res. Pap. 58, 493-504 (2011).

69. Holmkvist, L., Ferdelman, T. G. \& Jørgensen, B. B. A cryptic sulfur cycle driven by iron in the methane zone of marine sediment (Aarhus Bay, Denmark) Geochim. Cosmochim. Acta 75, 3581-3599 (2011).

70. Leloup, J. Sulfate-reducing bacteria in marine sediment (Aarhus Bay, Denmark): abundance and diversity related to geochemical zonation. Environ. Microbiol. 11, 1278-1291 (2009)

71. Leloup, J. et al. Diversity and abundance of sulfatereducing microorganisms in the sulfate and methane zones of a marine sediment, Black Sea. Environ. Microbiol. 9, 131-142 (2007).

72. Ravenschlag, K. et al. Community structure, cellular rRNA content and activity of sulfate-reducing bacteria in marine Arctic sediments. Appl. Environ. Microbiol. 66, 3592-3602 (2000)

73. Sahm, K., MacGregor, B. J., Jørgensen, B. B. \& Stahl, D. A. Sulphate reduction and vertical distribution of sulphate-reducing bacteria quantified by rRNA slot-blot hybridization in a coastal marine sediment. Environ. Microbiol. 1, 65-74 (1999).

74. Widdel, F. in Biology of Anaerobic Microorganisms (ed. Zehnder, A. J. B.) 469-586 (Wiley-Interscience, 1988)

75. McCollom, T. M. \& Amend, J. P. A thermodynamic assessment of energy requirements for biomass synthesis by chemolithoautotrophic microorganisms in oxic and anoxic environments. Geobiology 3, 135-144 (2005).

76. Detmers, J., Brüchert, V., Habicht, K. S. \& Kuever, J. Diversity of sulfur isotope fractionations by sulfatereducing prokaryotes. Appl. Environ. Microbiol. 67 888-894 (2001)

77. Knoblauch, C. \& Jørgensen, B. B. Effect of temperature on sulfate reduction, growth rate, and growth yield in five psychrophilic sulfate-reducing bacteria from Arctic sediments. Environ. Microbiol. 1 , 457-467 (1999).

78. Knoblauch, C., Jørgensen, B. B. \& Harder, J. Community size and metabolic rates of psychrophilic sulfate-reducing bacteria in Arctic marine sediments. Appl. Environ. Microbiol. 65, 4230-4233 (1999).

79. Tarpgaard, I. H., Boetius, A. \& Finster, K. Desulfobacter psychrotolerans sp. nov., a new psychrotolerant sulfate-reducing bacterium and descriptions of its physiological response to temperature changes. Antonie Leeuwenhoek $\mathbf{8 9}$, 109-124 (2006)

80. Schippers, A. \& Neretin, L. N. Quantification of microbial communities in near-surface and deeply buried marine sediments on the Peru continental margin using real-time PCR. Environ. Microbiol. 8 1251-1260 (2006)

81. Lin, L. H. et al. Long-term sustainability of a highenergy, low-diversity crustal biome. Science 314 479-482 (2006).

82. Price, B. \& Sowers, T. Temperature dependence of metabolic rates for microbial growth, maintenance, and survival. Proc. Natl Acad. Sci. USA 101, 4631-4636 (2004).

83. Berg, H. C. The rotary motor of bacterial flagella. Biochemistry 72, 19-54 (2003)

84. Fenchel, T. Motility of bacteria in sediments. Aquat. Microb. Ecol. 51, 23-30 (2008)

85. Lennon, J. T. \& Jones, S. E. Microbial seed banks: the ecological and evolutionary implications of dormancy. Nature Rev. Microbiol. 119, 119-130 (2011).

86. Johnson, S. S. et al. Ancient bacteria show evidence of DNA repair. Proc. Natl Acad. Sci. USA 104 14401-14405 (2007)

87. Hammes, F., Berney, M. \& Egli, T. Cultivationindependent assessment of bacterial viability. $A d v$. Biochem. Engineer. Biotechnol. 124, 123-150 (2012).

88. Schippers, A. et al. E. Prokaryotic cells of the deep sub-seafloor biosphere identified as living bacteria. Nature 433, 861-864 (2005)

89. Morono, Y. et al. Carbon and nitrogen assimilation in deep subseafloor microbial cells. Proc. Natl Acad. Sci. USA 108, 18295-18300 (2011).

A demonstration that metabolic activity is rapidly induced in most sub-seafloor cells.

90. D'Hondt, S. et al. Distributions of microbial activities in deep subseafloor sediments. Science 306 2216-2221 (2004).

91. D'Hondt, S. L. et al. Proceedings of the Ocean Drilling Program Vol. 201 (ed. Peters, L. L.) [online], http:// www-odp.tamu.edu/publications/201_IR/201TOC. HTM (2003)

92. Schrum, H. N., Spivack, A. J., Kastner, M. \& D'Hondt, S. Sulfate-reducing ammonium oxidation: a thermodynamically feasible metabolic pathway in subseafloor sediment. Geology 37, 939-942 (2009).

93. Lin, L. H. et al. Radiolytic H2 in continental crust: nuclear power for deep subsurface microbial communities. Geochem. Geophys. Geosystems 6 , Q07003 (2005). 
94. Blair, C. C., D'Hondt, S., Spivack, A. J. \& Kingsley, R. H. Radiolytic hydrogen and microbial respiration in subsurface sediments. Astrobiology 7 , 951-970 (2007)

95. Rang, C. U., Peng, A. Y. \& Chao, L. Temporal dynamics of bacterial aging and rejuvenation. Curr. Biol. 21 , 1813-1816 (2011)

96. Edgcomb, V. P., Beaudoin, D., Gast, R., Biddle, J. F. ¿ Teske, A. Marine subsurface eukaryotes: the fungal majority. Environ. Microbiol. 13, 172-183 (2011).

97. Danovaro, R. et al. Major viral impact on the functioning of deep-sea ecosystems. Nature 454, 1084-1087 (2008).

98. Engelhardt, T., Sahlberg, M., Cypionka, H. \& Engelen, B. Induction of prophages from deepsubseafloor bacteria. Environ. Microbiol. Rep. 3, 459-465 (2011)

99. Middelboe, M., Glud, R. N. \& Filippini, M. Viral abundance and activity in the deep sub-seafloor biosphere. Aquat. Microb. Ecol. 63, 1-8 (2011).

100. Brinton, K. L. F., Tsapin, A., Gilichinsky, D. \& McDonald, G. D. Aspartic acid racemization and agedepth relationships for organic carbon in Siberian permafrost. Astrobiology 2, 77-82 (2002).

101. Lindahl, T. \& Karlstrom, O. Heat-induced depyrimidination of deoxyribonucleic acid in neutra solution. Biochemistry 12, 5151-5154 (1973)

102. Lever, M. A. Acetogenesis in the energy starved deep biosphere - a paradox? Front. Microbiol. 2, 1-14 (2012).

103. Schink, B. in Biology of Anaerobic Microorganisms (ed. Zehnder, A. J. B.) 771-846 (Wiley-Interscience, 1988).

104. Schink, B. \& Stams, A. J. M. in The Prokaryotes: An Evolving Electronic Resource for the Microbiological Community (eds Dworkin, M. et al.) 309-335 (Springer, 2002).

105. Mitchell, P. Coupling of phosphorylation to electron and hydrogen transfer by a chemiosmotic type of mechanism. Nature 191, 144-148 (1961).

106. van den Vossenberg, J. L. C. M., Ubbink-Kok, T., Elferink, M. G. L., Driessen, A. J. M. \& Konings, W. N. Ion permability of the cytoplasmic membrane limits the maximum growth temperature of bacteria and archaea. Mol. Microbiol. 18, 925-932 (1995).

107. Van den Vossenberg, J. L. C. M., Driessen, A. J. M. \& Konings, W. N. in Cell and Molecular Response to Stress (eds Storey, K. B. \& Storey, J. M.) 71-88 (Elsevier, 2000).

108. Schlegel, K., Leone, V., Faraldo-Gómez, J. D. \& Müller, V. Promiscuous archaeal ATP synthase concurrently coupled to $\mathrm{Na}^{+}$and $\mathrm{H}^{+}$translocation Proc. Natl Acad. Sci. USA 109, 947-952 (2012).

109. Inagaki, F. et al. Biogeographical distribution and diversity of microbes in methane hydrate-bearing deep marine sediments on the Pacific Ocean Margin. Proc. Natl Acad. Sci. USA 103, 2815-2820 (2006)

110. Sørensen, K. B. \& Teske, A. Stratified communities of active archaea in deep marine subsurface sediments. Appl. Environ. Microbiol. 72, 4596-4603 (2006).

111. Schippers, A., Köweker, G., Höft, C. \& Teichert, M. A Quantification of microbial communities in forearc sediment basins off Sumatra. Geomicrobiol. J. 27 170-182 (2010).

112. Kubo, K. et al. Archaea of the Miscellaneous Crenarchaeotal Group are abundant, diverse, and widespread in marine sediments. ISME J. 6 1949-1965 (2012).

113. Schippers, A., Köck, D., Höft, C., Koweker, G. \& Siegert, M. Quantification of microbial communities in subsurface marine sediments of the Black Sea and off Namibia. Front. Microbiol. 3, 1-11 (2012).

114. Valentine, D. L. Adaptations to energy stress dictate the ecology and evolution of the Archaea. Nature Rev. Microbiol. 5, 316-323 (2007).

115. Van de Vossenberg, J. L. C. M. Ion permeability of the cytoplasmic membrane limits the maximum growth temperature of bacteria and archaea. Mol. Microbiol. 18, 925-932 (1995).

116. Takano, Y. et al. Sedimentary membrane lipids recycled by deep-sea benthic archaea. Nature Geosci. 3, 858-861 (2010).

117. Hoehler, T. M., Alperin, M. J., Albert, D. B. \& Martens, C. S. Apparent minimum free energy requirements for methanogenic archaea and sulfatereducing bacteria in an anoxic marine sediment. FEMS Microbiol. Ecol. 38, 33-41 (2001).

118. Shade, A. et al. Culturing captures members of the soil rare biosphere. Environ. Microbiol. 14, 2247-2252 (2012).

119. Rappe, M. S. \& Giovannoni, S. J. The uncultured microbial majority. Annu. Rev. Microbiol. 57, 369-394 (2003).

120. Stepanauskas, R. \& Sieracki, M. E. Matching phylogeny and metabolism in the uncultured marine bacteria, on cell at a time. Proc. Natl Acad. Sci. USA 104, 9052-9057 (2007).

121. Schrödinger, E. What is Life? The Physical Aspect of the Living Cell (Cambridge Univ. Press, 1944)

122. Duclaux, E. Traite de Microbiologie (Masson, 1900).

123. Marr, A. G., Nilson, E. H. \& Clark, D. J. The maintenance requirement of Escherichia coli. Ann. NY Acad. Sci. 102, 536-548 (1963).
124. Niejssel, O. M. \& Tempest, D. W. Bioenergetic aspects of aerobic growth of Klebsiella aerogenes NCTC 418 in carbon-limited and carbon-sufficient culture. Arch Microbiol. 107, 215-221 (1976).

125. Bulthuis, B. A., Frankena, J., Koningstein, G. M., van Verseveld, H. W. \& Stouthamer, A. H. A comparison between aerobic growth of Bacillus licheniformis in continuous culture and partial-recycling fermentor, with contributions to the discussion on maintenance energy demand. Arch. Microbiol. 152, 499-507 (1989).

126. Smith, D. C. et al. Methods for quantifying potential microbial contamination during deep ocean coring. ODP Technical Note 28 (doi:10.2973/odp.tn.28.2000) (2000).

127. Lever, M. A. et al. Trends in basalt and sediment core contamination during IODP Expedition 301. Geomicrobiol. J. 23, 517-530 (2006).

128. Edwards, K. J., Becker, K. \& Colwell, F. S. The deep, dark energy biosphere: intraterrestrial life on Earth Annu. Rev, Earth Planet. Sci. 40, 551-568 (2012).

129. Fry, J. C. et al. Prokaryotic populations and activities in an interbedded coal deposit, including a previously deeply buried section (1.6-2.3km) above $150 \mathrm{Ma}$ basement rock. Geomicrobiol. J. 26, 163-178 (2009).

130. Sahm, K., Macgregor, B. J., Jørgensen, B. B. \& Stahl, D. A. Sulfate reduction and vertical distribution of sulphate-reducing bacteria quantified by rRNA slotblot hybridization in a coastal marine sediment. Environ. Microbiol. 1, 65-74 (1999).

\section{Acknowledgements}

T.M.H. is supported by the NASA Astrobiology Institute and Exobiology Program, and B.B.J is supported by the Danish National Research Foundation, the German Max Planck Society and the European Research Council. The authors thank M. A. Lever, H. Røy, A. Schippers and an anonymous reviewer for helpful comments on the manuscript.

\section{Competing interests statement}

The authors declare no competing financial interests.

\section{FURTHER INFORMATION}

Tori M. Hoehler's homepage:

http://spacescience.arc.nasa.gov/staff/tori-hoehler

Bo Barker Jørgensen's homepage:

http://www.geomicrobiology.au.dk

Second International Workshop on Microbial Life under

Extreme Energy Limitation: http://www.microenergy2012.org

ALL LINKS ARE ACTIVE IN THE ONLINE PDF 